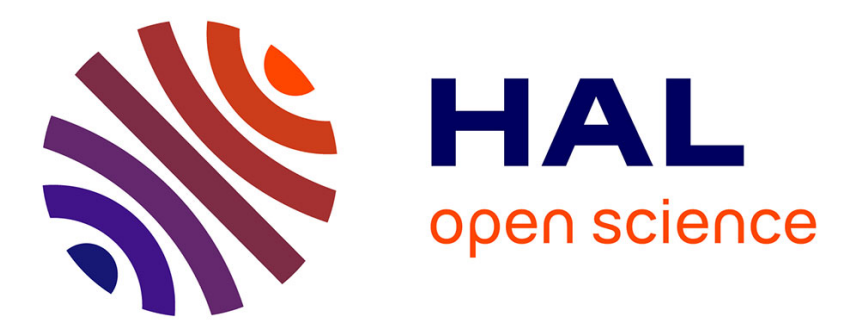

\title{
Responses of a non-migratory stock of brown trout, Salmo trutta, to ovine growth hormone treatment and seawater exposure

\author{
J.M.E. Almendras, Patrick Prunet, Gilles Boeuf
}

\section{- To cite this version:}

J.M.E. Almendras, Patrick Prunet, Gilles Boeuf. Responses of a non-migratory stock of brown trout, Salmo trutta, to ovine growth hormone treatment and seawater exposure. Aquaculture, 1993, 114, pp.169-179. 10.1016/0044-8486(93)90259-2 . hal-02715351

\author{
HAL Id: hal-02715351 \\ https://hal.inrae.fr/hal-02715351
}

Submitted on 1 Jun 2020

HAL is a multi-disciplinary open access archive for the deposit and dissemination of scientific research documents, whether they are published or not. The documents may come from teaching and research institutions in France or abroad, or from public or private research centers.
L'archive ouverte pluridisciplinaire HAL, est destinée au dépôt et à la diffusion de documents scientifiques de niveau recherche, publiés ou non, émanant des établissements d'enseignement et de recherche français ou étrangers, des laboratoires publics ou privés. 


\title{
Responses of a non-migratory stock of brown trout, Salmo trutta, to ovine growth hormone treatment and seawater exposure
}

\author{
J.M.E. Almendras ${ }^{1}$, P. Prunet and G. Boeuf ${ }^{a}$ \\ Laboratoire de Physiologie des Poissons, INRA, Campus de Beaulieu, Rennes, France \\ aIFREMER, Centre de Brest, Plouzané, France
}

(Accepted 11 December 1992)

\begin{abstract}
The ability of ovine growth hormone (oGH) to enhance the hypo-osmoregulatory performance of a non-migratory stock of the brown trout (Salmo trutta) was investigated. Three groups of juvenile fish were intraperitoneally implanted either with a cholesterol pellet (sham) or with a cholesterol pellet containing $250 \mu \mathrm{g} \mathrm{oGH}$ (treated); control fish did not receive any implant. While still in fresh water, the gill $\mathrm{Na}^{+} / \mathrm{K}^{+}$-ATPase activity of the oGH-treated group was four times higher than that of sham and control groups 2 weeks after implantation. Transfer to sea water (SW) resulted in marked increases in plasma electrolyte levels of the sham and control groups, whereas the oGH-treated group showed only minor perturbations in plasma electrolyte concentrations. Subsequent regulation of plasma electrolyte parameters to lower levels was slower or less effective in the non-treated groups than in the oGH-treated group. In the non-treated groups, SW exposure brought about significant increases in gill $\mathrm{Na}^{+} / \mathrm{K}^{+}$-ATPase activity but only after a time lag of 7 days. An additional significant increase in gill $\mathrm{Na}^{+} / \mathrm{K}^{+}$-ATPase activity was also observed in the oGH group 7 days after SW exposure. By the end of the experiment, oGH-treated fish were significantly larger than non-treated ones. The data indicate that after oGH administration, juvenile non-smoltifying brown trout respond to SW exposure in the same manner as a fully smolted salmonid.
\end{abstract}

\section{INTRODUCTION}

The salmonids, although mostly euryhaline, display a variety of patterns of osmoregulatory ability. Most of the migratory salmonids undergo a seasonal and complex smoltification process which is a preparation for downstream migration and marine life (Hoar, 1988). Among the many physiological changes that occur during smoltification is an increase in gill $\mathrm{Na}^{+} / \mathrm{K}^{+}$-ATPase activity (Zaugg and McLain, 1970, 1972; Boeuf and Prunet, 1985). This

Correspondence to: P. Prunet, Laboratoire de Physiologie des Poissons, INRA, Campus de Beaulieu, 35042 Rennes Cédex, France.

'Present address: SEAFDEC, TRS, 17 Times Street, West Triangle, Metro Manila, 1104 Philippines. 
increase, along with some physical changes, can be used as an indicator of the smolt's readiness for transfer to sea water (Boeuf and Harache, 1982). In non-smoltifying varieties, such as some brown trout (Salmo trutta) stocks, the only predictive criterion for a successful transfer is size, wherein larger fish stand a greater chance of surviving transfer.

Growth hormone (GH) has been shown to improve seawater adaptation in several salmonid species. Porcine GH pre-treatment increased the seawater survival in brown trout (Smith, 1956) and Atlantic salmon (Komourdjian et al., 1976). The enhancement of hypoosmoregulation by GH had also been demonstrated in other salmonids (Clarke et al., 1977; Richman and Zaugg, 1987) and recent studies have clearly shown the growth independent action of GH on seawater adaptation (Bolton et al., 1987; Collie et al., 1989; Boeuf et al., 1990; Madsen, 1990a,b). It has been shown that the major osmoregulatory action of GH occurs at the level of the gills (Prunet et al., 1993) which contain specific receptors for GH (Sakamoto and Hirano, 1991; Almendras, Auperin and Prunet, unpubl.).

Brown trout exist in a variety of stocks in European river systems; some are migratory while others are non-migratory (Ferguson, 1989; Jonsson, 1989). Recent trials in France have demonstrated that this species is a possible candidate for intensive marine aquaculture (Quillet et al., 1986, 1987; Fauré, 1991 ). However, the transfer of brown trout to sea water often results in considerable mortalities, especially if fish less than $50 \mathrm{~g}$ are used and the transfer occurs outside of spring (Boeuf and Harache, 1982, 1985; Quillet et al., 1986). Moreover, it is not the migrating stock that is best suited for intensive culture in terms of survival and growth during the freshwater and seawater phases of culture (Fauré, 1991). In this study, therefore, we address the question: To what extent can GH pre-treatment improve the osmoregulatory and growth performance after seawater exposure of a non-migratory stock of brown trout with an average weight of about $30 \mathrm{~g}$, a size at which fish have only a poor ability to withstand high salinity.

\section{MATERIALS AND METHODS}

\section{Animals}

The brown trout used in this study is an artificially bred strain, established by INRA in 1978, from a mixture of three domestic stocks from Denmark and the central and southwest regions of France (Krieg et al., 1992). Observations on successive generations of this strain at a hatchery facility of INRAIFREMER have shown a consistent absence of the indicators of smolting (i.e.: body silvering, fin darkening, springtime elevation of gill $\mathrm{Na}^{+} / \mathrm{K}^{+}$-ATPase ).

The fish (ave. BW $=29.41 \pm 2.49 \mathrm{~g}$ s.d.; $n=190$ ) were maintained in running fresh water in Ewos tanks $\left(4 \mathrm{~m}^{2}\right)$ under natural photoperiod $\left(48^{\circ} \mathrm{N}\right)$ and temperature $\left(10^{\circ} \mathrm{C}\right)$. They were acclimated to these conditions for 2 
weeks prior to the treatments. Fish were fed commercial dry pellets at a rate of $2-6 \%$ body weight per day by automatic feeders but were starved 2 days before SW exposure.

\section{Experimental protocols}

Fish were divided into three groups and were either untreated (control or $\mathrm{CN}$ ), or intraperitoneally implanted with a pellet of compacted cholesterol powder (sham implanted or SI) or with a pellet containing $250 \mu \mathrm{g}$ of ovine GH (NIADK-oGH-14) in the same cholesterol matrix (oGH-treated or GH) (Higgs et al., 1975; Boeuf et al., 1990). Each group was distinguished from the others by the presence or absence of the adipose fin and by the scar of implantation. Each pellet weighed $8-10 \mathrm{mg}$. The oGH-containing pellet released GH for a duration of 3-4 weeks (LeBail et al., unpubl.).

Seawater exposure ( 28 November 1990) was accomplished by turning off the freshwater (FW) supply to the tanks and replacing it with a seawater (SW) supply. In this manner the salinity in the tanks reached $35 \%$ in $2 \mathrm{~h}$.

\section{Sampling}

Ten fish were sampled prior to implantation and from each of the three groups 16 days after implantation just prior to $\mathrm{SW}$ exposure and thereafter at 2,7 and 14 days in SW.

During sampling, fish were stunned by a sharp blow to the head without anesthesia. Blood samples were collected from the caudal blood vessels using heparinized syringes. Plasma was collected after centrifugation and stored at $-20^{\circ} \mathrm{C}$ until analysis. Gill filaments were taken from the same fish, rinsed in $0.25 \mathrm{M}$ sucrose buffered at $\mathrm{pH} 7.4$ and immediately frozen in liquid nitrogen and stored at $-70^{\circ} \mathrm{C}$ until analysis. Gill $\mathrm{Na}^{+} / \mathrm{K}^{+}$-ATPase activity was measured according to the method described by Stagg and Shuttleworth (1982). Plasma chloride concentration was determined by amperometric titration (Isa Biologie CL 500) of $25 \mu \mathrm{l}$ undiluted plasma. Plasma sodium and calcium levels were determined by atomic absorption spectrophotometry using samples diluted 200 and 20 times, respectively.

\section{Calculations}

Statistical differences were analysed using one-way ANOVA followed by Student-Newman-Keuls multiple range test. The significance level used to establish significant differences was $5 \%$.

Weight data were log transformed to meet assumptions of normality and homogeneity of variance. Instantaneous growth rate was calculated from the formula $K=\left(\ln W_{1}-\ln W_{0}\right) /\left(t_{1}-t_{0}\right) \times 100$; where $\ln W_{1}$ and $\ln W_{0}$ are natural logarithms of weight at the end of the time interval $\left(t_{1}\right)$ and the start of the time interval $\left(t_{0}\right)$, respectively (Higgs et al., 1975). 


\section{RESULTS}

\section{Plasma electrolytes}

Plasma chloride concentrations (Fig. 1) of fish in FW were in the range of $120-130 \mathrm{mEq} \cdot 1^{-1}$ and did not change after application of the cholesterol pellets with or without GH. Exposure to SW resulted in dramatic increases in plasma chloride levels in CN (44\% above pre-transfer) and in SI ( $58 \%$ above pre-transfer) groups 2 days (Day 2) after SW exposure. However, these were regulated starting at Day 7 , and by Day 14 plasma chloride values had reached their lowest levels following SW transfer; these were about $15 \%$ above pretransfer values.

For the GH group, SW exposure did not cause as great an increase in plasma chloride concentrations as in the SI and CN groups and was immediately maintained at a low steady level of $140-145 \mathrm{mEq} \cdot 1^{-1}$

Plasma sodium (Fig. 2) and calcium (Fig. 3) concentrations showed roughly the same pattern of changes as the plasma chloride concentration before and after SW exposure. However, it appears that for the CN and SI groups, the regulation of plasma sodium and calcium to lower levels is slower than that shown for chloride of the same groups. In the GH group, SW exposure caused only slight increases in plasma sodium and calcium. Likewise, con-

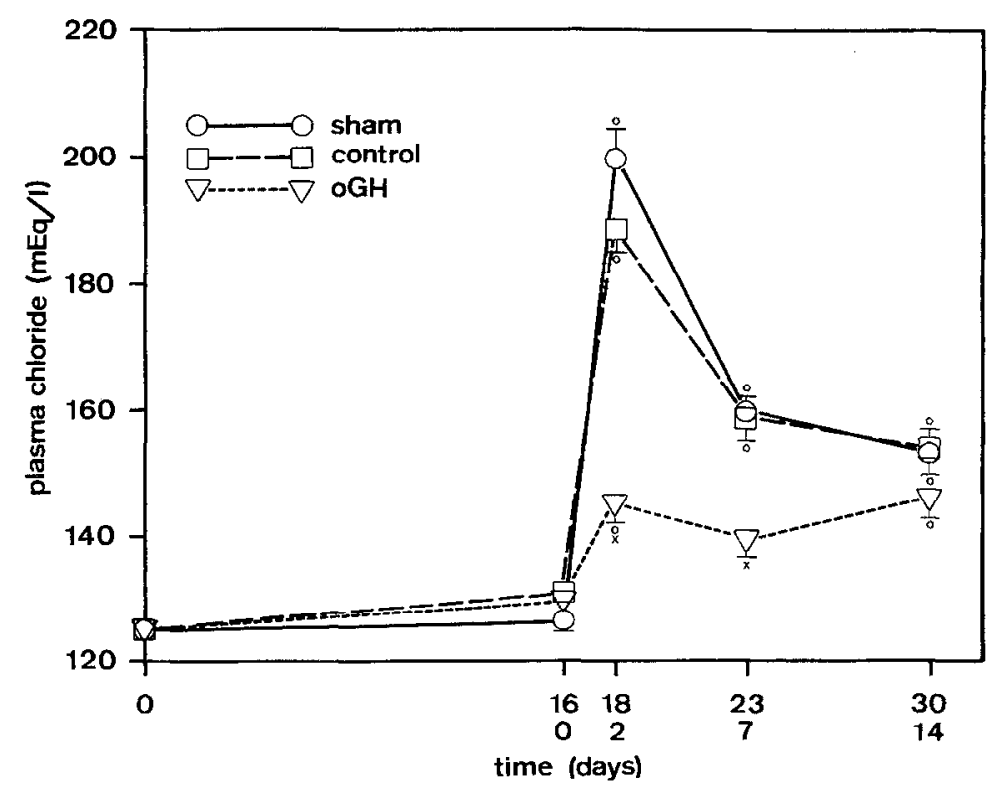

Fig. 1. Changes in plasma chloride levels in the brown trout in fresh water and after seawater exposure. Upper row of numbers on the $x$-axis represents days after implantation while lower row represents days in sea water. Each data point is a mean value from ten fish. $o=$ significantly different from preseawater exposure value; $x=$ significantly different from corresponding control value. 


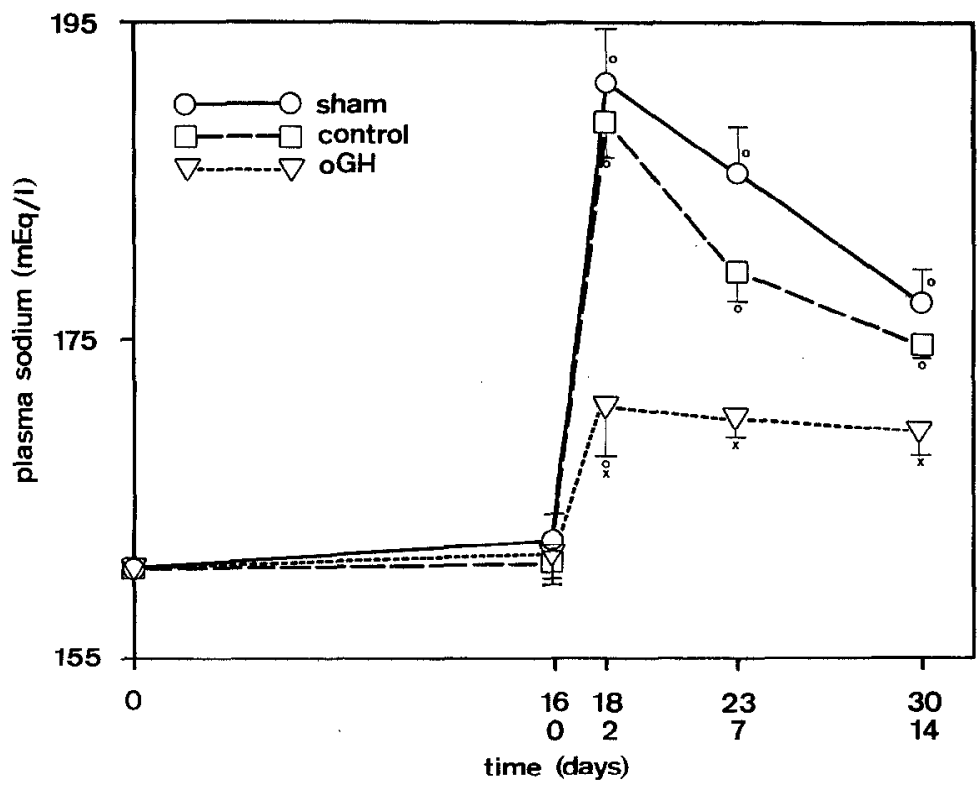

Fig. 2. Changes in plasma sodium levels in the brown trout in fresh water and after seawater exposure. See Fig. 1 for legends.

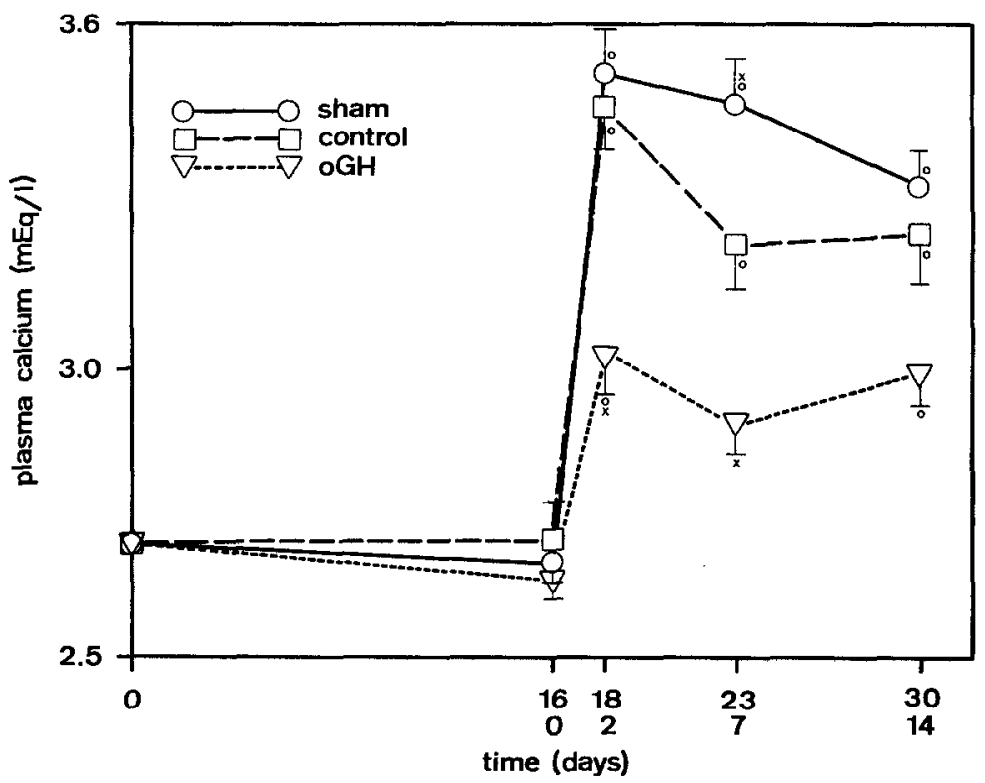

Fig. 3. Changes in plasma calcium levels in the brown trout in fresh water and after seawater exposure. See Fig. 1 for legends. 
stant low values were immediately achieved; these were about $170 \mathrm{mEq} \cdot \mathrm{1}^{-1}$ for sodium and $3.00 \mathrm{mEq} \cdot 1^{-1}$ for calcium.

Gill $\mathrm{Na}^{+} / \mathrm{K}^{+}$-ATPase

Gill $\mathrm{Na}^{+} / \mathrm{K}^{+}$-ATPase activity (Fig. 4) of the GH group was four times higher than that of the SI and CN groups, 16 days post-implantaton in FW. The $\mathrm{Na}^{+} / \mathrm{K}^{+}$-ATPase activity in the $\mathrm{CN}$ and SI groups did not change in FW and exposure to SW did not significantly change ATPase activity of these groups at Day 2. However, significant increases were observed in both groups at Day 7 followed by further significant increases at Day 14. Exposure to SW of the GH group brought about the same pattern of changes in gill $\mathrm{Na}^{+} / \mathrm{K}^{+}$ATPase activity as in the $\mathrm{CN}$ and SI groups, i.e. no change at Day 2 followed by increases at Day 7 and 14 . However, the $\mathrm{Na}^{+} / \mathrm{K}^{+}$-ATPase activity levels of the GH group were always significantly higher than corresponding values for the $\mathrm{CN}$ and SI groups at each of the samplings after implantation.

\section{Body weight change}

Ovine GH treatment significantly increased body weight gain in this species. Table 1 shows the initial weight and weights after 16 days in FW and after 14 days in SW. All three groups showed significant increases in weight

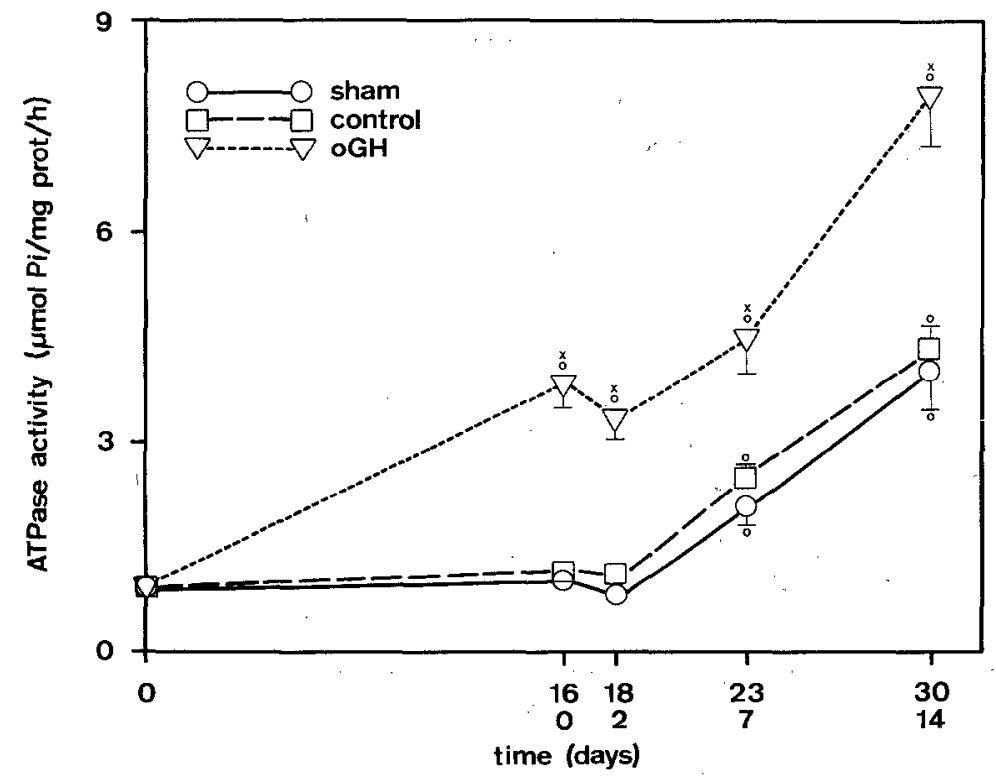

Fig. 4. Levels of branchial $\mathrm{Na}^{+} / \mathrm{K}^{+}$-ATPase activity in the brown trout in fresh water and after seawater exposure. Each data point is a mean value of seven to ten fish. $0=$ significantly different from pre-implantation value, $\mathrm{x}=$ significantly different from corresponding control. 
TABLE 1

Weights and instantaneous growth rates of non-treated and oGH-treated brown trout

\begin{tabular}{llll}
\hline Days after implantation & Sham & Control & oGH \\
\hline 0 & & $29.41 \pm 0.18^{\mathrm{a}}$ & \\
$16(16$ days in FW) & $33.64 \pm 1.26^{\mathrm{b}}$ & $35.90 \pm 1.34^{\mathrm{b}}$ & $35.27 \pm 1.33^{\mathrm{b}}$ \\
$30(14$ days in SW) & $31.66 \pm 1.22^{\mathrm{b}}$ & $35.47 \pm 2.70^{\mathrm{b}}$ & $44.40 \pm 1.83^{\mathrm{c}}$ \\
$\begin{array}{l}\text { Instantaneous } \\
\text { growth rate (\%/day) }\end{array}$ & 0.25 & 0.62 & 1.37 \\
\hline
\end{tabular}

Values are means \pm standard error of the mean $(n=10$ except Day 0 where $n=190)$. Values with different superscripts are significantly different at $P<0.05$.

after 16 days in FW but at this point the GH group was not significantly larger than either CN or SI. However, after 14 days in SW only the GH group had gained weight significantly. Instantaneous growth rate calculations showed that the GH group had a faster weight increase than $\mathrm{CN}$ which had a faster weight increase than the SI group.

\section{Mortalities}

At the end of the experiment, a cumulative total of nine fish had died in the SI group, ten in the $\mathrm{CN}$ and none in the $\mathrm{GH}$ group.

\section{DISCUSSION}

Sedentary non-smoltifying varieties of salmonids such as the brown trout stock used in this study lack the seasonal increase in gill $\mathrm{Na}^{+} / \mathrm{K}^{+}$-ATPase activity that generally characterizes smoltifying salmonids (Zaugg and McLain, 1970; Boeuf and Harache, 1982). The results of the present study show that GH treatment can increase branchial $\mathrm{Na}^{+} / \mathrm{K}^{+}$-ATPase activity in a nonsmoltifying variety of the brown trout. This four-fold increase in ATPase activity occurred in the $\mathrm{GH}$ fish while still in $\mathrm{FW}$, indicating that the branchial ion extrusion mechanism of the oGH-treated brown trout was already well established prior to SW exposure. Consequently, GH-treated fish show a good ability to withstand direct transfer to SW as indicated by the absence of any significant disequilibrium in their hydromineral balance. These results are in agreement with previous data on the GH osmoregulatory effect in sea trout parr (Madsen, 1990b). Similar results were reported earlier for Atlantic salmon pre-smolts treated with oGH implants (Boeuf et al., 1990) and for Atlantic salmon smolts (Pisam et al., 1988; Boeuf et al., 1990). However, the administration of GH as repeated injections in sea trout parr (Madsen, 1990a) or in the rainbow trout (Bolton et al., 1987; Madsen, 1990b) did not lead to such a strong SW adaptability when fish were transfered to $26-28 \%$ salinity. 
To obtain a pattern of SW adaptation similar to that which was shown in our study (where fish had to withstand a full 35\% salinity), Madsen (1990a) had to use a combination of oGH and cortisol treatments. This discrepancy was observed even though Madsen used a total of $850 \mu \mathrm{g}$ oGH as repeated injections in $53 \mathrm{~g}$ fish whereas only $250 \mu \mathrm{g}$ oGH was used in this experiment as a single implant in $30 \mathrm{~g}$ fish. The possibility that the cholesterol used in the pellet in the present work may have acted as a precursor to cortisol can be ruled out as fish implanted with the cholesterol alone (shams) did not show any signs of enhanced SW adaptability. The important difference between these studies is the mode of GH administration (injection versus pellet implantation ). This would certainly lead to different plasma profiles of exogenous GH during the treatment period as was shown in the rainbow trout where $\mathrm{bGH}$, administered in a cholesterol pellet, sustained significantly higher plasma GH levels for a period of 3 weeks than did a single injection of the same dose (P-Y. LeBail et al., unpubl.; Down et al., 1988a). However, comparison of the effects of these two modes of administration on growth response in coho salmon did not lead to significant differences (Down et al., 1988b). Physiological differences between non-smoltifying brown trout and the sea trout may also explain the different responses observed in these studies. Clearly; more information is needed to understand the functional limitation of $\mathrm{GH}$ actions on hypoosmoregulation.

The exact mechanism of action of GH on osmoregulatory organs is yet unknown. Several arguments support the gill as an important site of GH action. Recent studies by Prunet and co-workers (1993) have shown that in vivo application of GH in Atlantic salmon pre-smolt increases the number and activity of $\alpha$-type chloride cells whereas it decreases the number of $\beta$-type chloride cells. This response was associated with the development of hypoosmoregulation as indicated by the increase in gill $\mathrm{Na}^{+} / \mathrm{K}^{+}$-ATPase activity and the ability of the fish to excrete $\mathrm{Na}^{+}$branchially when transferred to SW. This result, and the presence of $\mathrm{GH}$ receptors in gill membrane preparations ( $\mathrm{Sa}$ kamoto and Hirano, 1991; Almendras, Auperin and Prunet, unpubl. ), would argue for a direct action of $\mathrm{GH}$ on chloride cells. On the other hand, cortisol and insulin-like-growth factor I (IGF-I) have also been shown to enhance hypoosmoregulation in salmonids (Richman and Zaugg, 1987; Madsen, 1990a,b; McCormick et al., 1991 ). Since intact fish were used in the present study, it is possible that the observed GH effect may have been due to a stimulation of IGF-I production by GH (Sakamoto et al., 1991) or it may have been augmented by increased endogenous cortisol levels as GH enhances interrenal sensitivity to ACTH (Young, 1988).

Analysis of growth performance in our experiment showed that the GH group was not significantly larger than $\mathrm{CN}$ and SI groups during the freshwater phase of the experiment. One could assume that non-treated fish already had optimal growth and that GH treatment could not improve their growth 
rate over such a short period of time. In coho salmon, using the same mode of administration and higher bovine GH doses, Down et al. (1988a) also reported no apparent effect on percent weight gain during the first 2 weeks of treatment. In our experiment, a complete cessation of growth was observed in the non-treated groups after exposure to SW. Similarly, a transient reduction in appetite and growth after transfer to SW has been reported in other salmonids by several authors (Saunders and Henderson, 1969a,b; Shaw et al., 1975; Clarke et al., 1981; Usher et al., 1991). Although the high metabolic cost of osmoregulation was suggested to explain this observation, little evidence is available to support this hypothesis (Usher et al., 1991). In our study, GH treatment brought about a significant weight increase in the brown trout exposed to SW. Such a growth effect after hormonal treatment could be explained by an improved adaptation to the hyperosmotic environment which directly (reduced metabolic cost of osmoregulation ) or indirectly (reduced stress) had positive effects on growth physiology. Further studies are needed to clarify the exact relationship between osmoregulation and growth physiology in salmonids.

In conclusion, juvenile non-smoltifying brown trout pre-treated with $\mathrm{GH}$ responded to $S W$ exposure like fully smoltified fish even at sizes of less than $30 \mathrm{~g}$. Since marine aquaculture of salmonids involves the transfer of young fish to SW, a critical phase that can greatly influence their subsequent performance, the enhancement of hypoosmoregulation by $\mathrm{GH}$ administration will not only reduce the risk of high mortalities during transfer but also ensure subsequent good growth and survival during the grow-out phase.

\section{ACKNOWLEDGEMENTS}

We wish to thank Region Bretagne (BRITTA Program) for financial support. We acknowledge the National Hormone and Pituitary Program of the National Institute of Diabetes, Digestive and Kidney Diseases (NIDDK), University of Maryland School of Medicine for the gift of ovine growth hormone (NIADKK-oGH-15). We are also indebted to A. Le Roux, A. Severe, Dr. P.-Y. Le Bail, J.-M. Tanguy, B. Auperin, O. Sandra and E. G. de Jesus.

\section{REFERENCES}

Boeuf, G. and Harache, Y., 1982. Criteria for the adaptation of salmonids to high salinity seawater in France. Aquaculture, 28: 163-176.

Boeuf, G. and Prunet, P., 1985. Measurement of gill $\mathrm{Na}^{+} / \mathrm{K}^{+}$-ATPase activity and plasma thyroid hormones during smoltification in Atlantic salmon (Salmo salar L.). Aquaculture, 82: 257-268.

Boeuf, G., LeRoux, A., Severe, A., Prunet, P. and LeBail, P.Y., 1990. The role of growth hormone in the adaptability of Atlantic salmon (Salmo salar) to sea water. In: R.L. Saunders 
(Editor), Proceedings of Canada-Norway Finfish Aquaculture Workshop, 11-14 September 1989. Can. Tech. Rep. Fish. Aquat. Sci. 1761, pp. 125-131.

Bolton, J., Collie, N.L., Kawauchi, M. and Hirano, T., 1987. Osmoregulatory actions of growth hormone in rainbow trout (Salmo gairdneri). J. Endocrinol., 112: 63-68.

Clarke, W.C., Farmer, S.C. and Hartwell, K.M., 1977. Effect of teleost pituitary growth hormone on growth of Tilapia mossambica and on growth and seawater adaptation of sockeye salmon (Oncorhynchus nerka). Gen. Comp. Endocrinol., 33: 174-178.

Clarke, W.C., Shelbourne, J.E. and Brett, J.R., 1981. Effect of artificial photoperiod cycles, temperature, and salinity on growth and smolting in underyearling coho (Oncorhychus kisutch), chinook (O. tshawytscha), and sockeye (O. nerka) salmon. Aquaculture, 22: 105116.

Collie, N.L., Bolton, J.P., Kawauchi, H. and Hirano, T., 1989. Survival of salmonids in seawater and time-frame of growth hormone action. Fish Physiol. Biochem., 7: 315-321.

Down, N.E., Donaldson, E.M., Dye, H.M., Langley, K. and Souza, L.M., 1988a. Recombinant bovine somatotropin more than doubles the growth rate of coho salmon (Oncorhynchus kisutch) acclimated to seawater and ambient winter conditions. Aquaculture, 68: 141-155.

Down, N.E., Dye, H.M., Donaldson, E.M., and Souza, L.M., 1988b. Plasma kinetics of injected recombinant chicken somatotropin in juvenile salmon (Oncorhynchus kisutch) using a homologous radioimmunoassay. Fish Physiol. Biochem., 5: 49-57.

Fauré, A., 1991. La Truite Fario, vers une filière salmonicole marine a la française? Aqua Revue (Fevrier-Mars, 1991), 35: 7-13.

Ferguson, A., 1989. Genetic differences among brown trout, Salmo trutta, stocks and their importance. Freshwater Biol., 21: 35-46.

Higgs, D.A., Donaldson, E.M., Dye, H.M. and McBride, J.R., 1975. A preliminary investigation of the effect of bovine growth hormone on growth and muscle composition of coho salmon (Oncorhynchus kisutch). Gen. Comp. Endocrinol., 27: 240-253.

Hoar, W.S., 1988. The physiology of smolting salmonids. In: W.S. Hoar and D.J. Randall (Editors), Fish Physiology, Vol. II, Part B. Academic Press, New York, pp. 275-343.

Jonsson, B., 1989. Life history and habitat use of Norwegian brown trout (Salmo trutta). Freshwater Biol., 21: 71-86.

Komourdjian, M.P., Saunders, R.L. and Fenwick, J.C., 1976. The effect of porcine somatotropin on growth and survival in seawater of Atlantic salmon (Salmo salar) parr. Can. J. Zool., 54: 531-535.

Krieg, F., Quillet, E. and Chevassus, B., 1992. Brown trout, Salmo trutta L.: a new species for intensive marine aquaculture. Aquacult. Fish. Manage., 23: 557-566.

Madsen, S.S., 1990a. The role of cortisol and growth hormone in seawater adaptation and development of hypoosmoregulatory mechanisms in sea trout parr (Salmo trutta trutta). Gen. Comp. Endocrinol., 79: 1-11.

Madsen, S.S., 1990b. Enhanced hypoosmoregulatory response to growth hormone after cortisol treatment in immature rainbow trout, Salmo gairdneri. Fish Physiol. Biochem., 8: 271-279.

McCormick, S.D., Sakamoto, T., Hasegawa, S. and Hirano, T., 1991. Osmoregulatory actions of insulin-like growth factor I in rainbow trout (Oncorhynchus mykiss). J. Endocrinol., 130: 87-92.

Pisam, M., Prunet, P., Boeuf, G. and Rambourg, A., 1988. Ultrastructural features of chloride cells in the gill epithelium of the Atlantic salmon, Salmo salar, and their modifications during smoltification. Am. J. Anat., 183: 235-244.

Prunet, P., Pisam, M. and Rambourg, A., 1993. Effect of growth hormone on gill chloride cells in juvenile Atlantic salmon (Salmo salar). (Submitted to Am. J. Physiol.).

Quillet, E, Chevassus, B. and Krieg, F., 1986. Etude des possibilitiés de transfert automnal en mer de juvéniles de truite fario (Salmo trutta). Bull. Fr. Pêche Piscic., 303: 125-133.

Quillet, E., Chevassus, B. and Krieg, F., 1987. Characterization of auto- and allotriploid salmonids for rearing in seawater cages. In: K. Tiews (Editor)., Proc. World Symp. on Selec- 
tion, Hybridization and Genetic Engineering in Aquaculture, Bordeaux, France, 27-30 May 1987. Vol. II. Berlin, pp. 239-252.

Richman, N.H. III and Zaugg, W.S., 1987. Effects of cortisol and growth hormone on osmoregulation in pre- and desmoltified coho salmon (Oncorhynchus kisutch). Gen. Comp. Endocrinol., 65: 189-198.

Sakamoto, T. and Hirano, T., 1991. Growth hormone receptors in the liver and osmoregulatory organs of rainbow trout: characterization and dynamics during adaptation to seawater. $\mathbf{J}$. Endocrinol., 130: 425-433.

Sakamoto, T., Iwata, M. and Hirano, T., 1991. Kinetic studies of growth hormone and prolactin during adaptation of coho salmon, Oncorhynchus kisutch, to different salinities. Gen. Comp. Endocrinol., 53: 353-364.

Saunders, R.L. and Henderson, E.B., 1969a. Survival and growth of Atlantic salmon parr in relation to salinity. Fish. Res. Board Can. Tech. Rep. 147, 13 pp.

Saunders, R.L. and Henderson, E.B., 1969b. Growth of Atlantic salmon smolts and post-smolts in relation to salinity, temperature and diet. Fish. Res. Board Can. Tech. Rep. 149, 31 pp.

Shaw, H.H., Saunders, R.L. and Hall, H.C., 1975. Environmental salinity: its failure to influence growth of Atlantic salmon (Salmo salar) parr. J. Fish. Res. Board Can., 32: 1821-1824.

Smith, D.C.W., 1956. The role of the endocrine organs in the salinity tolerance of trout. Mem. Soc. Endocrinol., 5: 83-101.

Stagg, R.M. and Shuttleworth, T.J., 1982. $\mathrm{Na}^{+} / \mathrm{K}^{+}$-ATPase, ouabain binding and ouabain-sensilive oxygen consumption in gills from Platichthys flesus. J. Comp. Physiol., 147: 93-99.

Usher, M.L., Talbot, C. and Eddy, F.B., 1991. Effects of transfer to seawater on growth and feeding in Atlantic salmon smolts (Salmo salar L.). Aquaculture, 94: 309-326.

Young, G., 1988. Enhanced response of the interrenal of coho salmon (Oncorhynchus kisutch) to ACTH after growth hormone treatment in vivo and in vitro. Gen. Comp. Endocrinol., 71: $85-92$.

Zaugg, W.S. and McLain, L.R., 1970. Adenosine triphosphatase activity in gills of salmonids: seasonal variations and salt water influence in coho salmon, Oncorhychus kisutch. Comp. Biochem. Physiol., 35A: 587-596.

Zaugg, W.S. and McI-ain, L.R., 1972. Changes in gill ATPase activity associated with parrsmolt transformation in steelhead trout (Salmo gairdneri), coho (Oncorhynchus kisutch) and spring chinook salmon (Oncorhynchus tshawytscha). J. Fish. Res. Board Can., 29: 167171. 